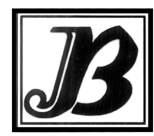

J. Bio-Sci. 29(1): 33-48, 2021 (June)

ISSN 1023-8654 http://www.banglajol.info/index.php/JBS/index DOI: https://doi.org/10.3329/jbs.v29i0.54820

\title{
PRODUCTION OF PROTEASE ON WHEAT BRAN BY A NEWLY ISOLATED STREPTOMYCES SP. UNDER SOLID STATE FERMENTATION
}

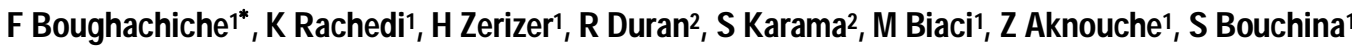 \\ and A Boulahrouf 3 \\ ${ }^{1}$ Biotechnology and Food Quality Laboratory, Institute of Nutrition and Food Processing Technologies, \\ Mentouri Brother University, Constantine 1, Algeria \\ ${ }_{2}^{2}$ Team Environment and Microbiology, UMR 5254, IPREM. University of Pau and Pays de I'Adour, France \\ ${ }_{3}^{3}$ Microbiological Engineering and Applications Laboratory, Mentouri Brother University, Algeria
}

\begin{abstract}
Proteases are a group of enzymes that catalyse the degradation of proteins resulting in the production of their amino acid constituents. In the present study newly isolated Streptomyces sp. was subjected to produce proteases through solid state fermentation while wheat bran was used as substrate. To produce proteases, a local strain Streptomyces sp. was isolated from a soil sample of Ezzemouls saltpan, located in Ain M'lila (East of Algeria). The phenotypic and phylogenetic studies of this strain showed that it represents probably a new species. The SSF production medium for Streptomyces sp. was optimized using Plackett and Burman statistical methods. The results showed a maximum activity on basal wheat bran medium supplemented with $1 \%$ fructose. The best SSF humidifying solution was $\mathrm{pH} 9.0$ phosphate buffer at $50 \%$ moisture. Protease has an optimum at $\mathrm{pH} 7.0$, which is a typical characteristic of neutral proteases. The optimum temperature was $60^{\circ} \mathrm{C}$ and proved stable up to $80^{\circ} \mathrm{C}$. The results showed that the novel Streptomyces sp. isolate is a good producer of extracellular neutral protease on wheat bran, which can be beneficial for industries.
\end{abstract}

Key words: Optimization, Protease, Solid state fermentation, Streptomyces, Wheat bran

\section{Introduction}

Proteases (EC) are the most important industrial enzymes and widespread in nature. Microbial proteases belong to acid, neutral or alkaline based on their pH optimum for activity, active sites and may depend on the composition of the medium. Culture conditions play significant role on growth and production of protease by bacteria (Padmapriya and Christudhas 2012). Although protease production is an inherent capability of all microorganisms, the microbes that produce a substantial amount of extracellular proteases are of industrial importance (Bhunia et al. 2012) that can have application in various fields such as leather processing, food processing, pharmaceutical and bioremediation process (Sankaralingam et al. 2012). Bacterial proteases for industrial uses are produced and studied mainly from Bacillus and Streptomyces species. The possibility of using Streptomyces for protease production has been investigated because of their capacity to secrete the proteases into extra cellular media, which can generally be regarded as safe (Jayasree et al. 2009). Further the use of solid state fermentation (SSF) for production of enzymes and other products has many advantages over submerged fermentation (Lonsane and Ramesh 1990). These advantages include: easier recovery of products, the absence of foam formation and contamination risks can significantly reduce due to the low water contents. Moreover, it permits the use of agricultural and agro-industrial residues, as

*Author for correspondence: faizasasi@yahoo.fr 
substrates which are converted into products with high commercial value (Lonsane and Ramesh 1990, Pandey 1992). Therefore, the present work aimed to characterise Streptomyces $\mathrm{sp}$. and then focus on optimizing the production of extracellular protease in solid state fermentation on wheat bran.

\section{Materials and Methods}

\section{Isolation and screening of proteolytic bacterial strain}

Soil samples were taken from Ezzemoul saltpan (located in East of Algeria $006^{\circ} 34^{\prime} \mathrm{E}, 036^{\circ} 02^{\prime} \mathrm{N}$ ) and used for the isolation of bacteria on M4 medium (Agar (18 g/l, DIFCO, USA), yeast extract (3 g/l, DIFCO, USA), malt extract ( $3 \mathrm{~g} / \mathrm{l}, \mathrm{DIFCO}, \mathrm{USA})$, peptone ( $5 \mathrm{~g} / \mathrm{l}, \mathrm{DIFCO}, \mathrm{USA})$ and glucose $(10 \mathrm{~g} / \mathrm{l}, \mathrm{DIFCO}, \mathrm{USA})$. A total of 5 isolates of actinobacteria were isolated and purified by streaking on agar plates. The isolates were examined for various morphological and biochemical characteristics as per Bergey's Manual of determinative Bacteriology (1994). Isolated strains were tested for protease production on skim milk agar plates. After 7 days of incubation at $30^{\circ} \mathrm{C}$, the proteolytic activity was confirmed by clear zone formation around the bacterial growth. The most potential strain was chosen for the rest of the study.

\section{Strain identification}

\section{Morphological study}

Streptomyces sp. strain colonies were characterized morphologically on different media (ISP2, ISP3, ISP4, ISP5; ISP: International Streptomyces Project), Starch casein agar, Glucose asparagine agar, Hickey and Tresner agar) following the directions given by the International Streptomyces Project (Shirling and Gottlieb 1966). Cultural characteristics such as growth importance, aerial and substrate mycelium colour and diffusible pigment production, were recorded after incubation for 7,14 and 21 days at $28^{\circ} \mathrm{C}$. Micromorphological observations were carried out with a light microscope using two different methods: slide culture technique (Zaitlin et al. 2003) and inclined coverslips technique (Williams and Cross 1971, Holt et al. 1994).

\section{Phylogenetic study}

Studied strain DNA was extracted using DNA extraction kit (Ultraclean Microbial DNA Isolation (Mol. Biol). 16S rRNA genomic regions were then analyzed using 63F (5'-CAGGCCTAACACATGCAAGTC-3') and 1387R (5'-GGGCGGWGTGTACAAGGC-3') as forward and reverse primers, respectively. Amplification was carried out by AB Applied Biosystems Veriti 96 well thermal cycler, using Taq DNA polymerase. Polymerase chain reaction (PCR) program was $95^{\circ} \mathrm{C} / 10$ min for initial denaturing, $95^{\circ} \mathrm{C} / 45 \mathrm{~s}, 56^{\circ} \mathrm{C} / 45 \mathrm{~s}, 72^{\circ} \mathrm{C} / 1 \mathrm{~min}$ for 36 cycles and $72^{\circ} \mathrm{C} / 10$ min for final extension. PCR products were electrophorized on agarose gel with Tris Borate EDTA in Embi Tec Runone TM electrophoresis cell, under 100 volts. The gel was finally photographed on a UV Imager Master® VDS (Pharmacia Biotech). Purified products were subjected to $16 \mathrm{~S}$ rRNA sequencing by automated Sanger method (Sanger et al. 1977) using 1387R primer, at (GATC Biotech AG, Germany) laboratory. The sequences were finally corrected using the software (Sequencer v. 4.1.4, Gene Codes). Sequences were analysed by MEGA 5 software (Tamura et al. 2011) and nBLAST tool at $\mathrm{NCBI}$. The 16S rRNA nucleotide sequence of the isolate was aligned with homologous regions from various actinobacteria, and the phylogenetic tree was constructed by neighbour-joining method (Saitou and Nei 1987). A bootstrap confidence analysis was performed on 1000 replicates to determine the reliability of the distance tree topologies obtained. 


\section{Physiological and biochemical studies}

The physiological and biochemical characteristics were determined according to the methods of Shirling and Gottlieb (1966), Crawford et al. (1993), Chaphalkar and Dey (1996) and Singleton (1999).

\section{Solid state fermentation (SSF) and enzyme assay}

$5 \mathrm{~g}$ of wheat bran from the mill (Esalaam-JJJEL) were introduced into $250 \mathrm{ml}$ Erlenmeyer flasks then moistened with $10 \mathrm{ml}$ of humidifying solution. The medium was inoculated with $10^{6} \mathrm{spores} / \mathrm{ml}$. Incubation is carried out in a shaking water bath at two temperatures $\left(30^{\circ} \mathrm{C}\right.$ and $37^{\circ} \mathrm{C}$ ) for two time intervals ( 2 days and 5 days). After fermentation, the fermented substrate was ground manually and then mixed with $40 \mathrm{ml}$ of buffer solutions. The mixture was homogenised in an agitator for $30 \mathrm{~min}$ and then centrifuged at $11000 \mathrm{~g}$ for $20 \mathrm{~min}$ at $4^{\circ} \mathrm{C}$. The clear supernatant was used as crude enzyme. Protease activity was measured following by the methods of Tsuchida et al. (1986).

\section{Optimization of wheat bran based medium for protease production}

\section{Optimization of humidifying solution}

The influence of the humidifying agent in SSF on protease production was evaluated by the use of three different solutions at neutral pH (distilled water, phosphate buffer, salt solution) for moistening wheat bran. The fermentation was carried out under the same conditions mentioned above. In the second stage, the pH of the humidifying solutions was varied from 7 to 10 . Finally, the moisture content of solid fermentation was optimized by incubation of the studied strain at different volumes of the humidifying solution, which correspond to the different moisture levels: 40, 50,60, 70 and 80\%.

\section{Effect of supplementation carbon and nitrogen sources and salts on protease production}

The influence of supplementary carbon and nitrogen sources and mineral salts to wheat bran, on production of protease by selected Streptomyces sp. strain was investigated following Plackett and Burman design (Plackett and Burman 1946). The 7 independent variables (including 2 dummy variables) were organized in 8 combinations. Each variable was examined at a high level (coded as +1 ) and a low level (coded as -1$)$. The experimental values of the coded levels are shown in table1. Plackett and Burman (1946) design is based on the first order polynomial model: $Y=\beta 0+\Sigma \beta i X i$ where $Y$ is the response (protease enzyme production), $\beta 0$ is the models intercept, $\beta i$ is the linear coefficient and $X i$ is the level of the independent variable. All the experiments were carried out in triplicates.

Table 1. Experimental description for the Plackett and Burman design

\begin{tabular}{lcc}
\hline \multicolumn{1}{c}{ Factors } & Low level $(-1)^{\star}$ & High level $(+1)^{\star}$ \\
\hline X1 : glucose & 0 & $1 \%$ \\
X2 : fructose & 0 & $1 \%$ \\
X3 : error & - & - \\
X4 : casein & 0 & $1 \%$ \\
X5 : gelatin & 0 & $1 \%$ \\
X6 : error & - & - \\
X7 : NaCl & 0 & $0.1 \%$ \\
\hline
\end{tabular}

${ }^{*}$ Concentrations in $(g / l)$. 


\section{$\mathrm{pH}$ and temperature effects on protease activity}

For determination of optimum $\mathrm{pH}$ of the enzyme, the reaction mixture buffer was varied over the $\mathrm{pH}$ range 3.0 to 12.0 . Similarly, enzyme production was also monitored at temperature in the range of 20 to $90^{\circ} \mathrm{C}$ (in increment of $10^{\circ} \mathrm{C}$ ).

\section{Protease thermal stability}

The enzyme was incubated at different temperature values $\left(60,70,80\right.$ and $\left.90^{\circ} \mathrm{C}\right)$ for $120 \mathrm{~min}$. The samples were submitted to determination of protease activity every $30 \mathrm{~min}$.

\section{Results and Discussion}

\section{Isolation and screening of protease producing strain}

The actinobacterial strain (coded SS) was isolated from the soil of Ezzemoul Saltpan under sterile conditions. After purification, the proteolytic activity was confirmed by clear zone formation around the bacterial growth due to the casein hydrolysis.

\section{Identification of protease producing strain}

\section{Morphology and cultural characteristics}

The studied Streptomyces strain has a very good growth on all media tested except for ISP5 medium (Table 2). This microorganism will be classified in the grey series because of the predominance of this colour in the aerial mycelium, it is only the ISP5 medium that gives a greyish white colour of this mycelium. The back of the colony (vegetative mycelium) varied from white, greyish pink to grey. This pigment was intracellular but has diffused on ISP2, ISP7, casein starch and Hickey and Tresner media and was insensitive to pH changes. By studying the morphological properties, it was found that SS strain aerial mycelia formed unfragmented, branched, straight hyphae bearing non motile cylindrical spores. Spores chains were related to Rectiflexible (RF) category and contained up to 40 spores per chain.

Table 2. Cultural characteristics of SS strain

\begin{tabular}{lcccc}
\hline \multirow{2}{*}{ Time } & Culture media & Growth & \multicolumn{2}{c}{ Pigmentation } \\
\cline { 4 - 5 } (day) & & characteristics & Substrate mycelium & Aerial mycelium \\
\hline $7^{\text {th }}$ & ISP2 & Good & Greyish pink & Grey (dark medium) \\
& ISP3 & Good & Dark grey & Grey \\
ISP4 & Good & Grey & Grey \\
ISP5 & Moderate & Light pink & White \\
ISP6 & Good & White & Light grey \\
& ISP7 & Good & Brown beige & Grey (Grey pink) \\
& Glucose asparagine & Moderate & Red & Light grey \\
& Starch casein & Good & White & Grey (dark medium) \\
& Hickey and Tresner & Good & Dark grey pink & Grey (+pigment) \\
\hline
\end{tabular}


Contd. Table 2

\begin{tabular}{cccc}
\hline 14 $^{\text {th }}$ ISP2 & Good & Greyish pink & Grey (dark medium) \\
ISP3 & Good & Dark grey & Grey \\
ISP4 & Good & Grey & Grey \\
ISP5 & Moderate & Light pink & Greyish white \\
ISP6 & Good & White & Light grey \\
ISP7 & Good & Beige & Grey with white center \\
Glucose asparagine & Good & Grey white & Light grey \\
Starch casein & Good & White & Grey (dark medium) \\
Hickey and Tresner & Good & Dark grey pink & Dark grey (+pigment) \\
\hline ISP2 & Good & Greyish pink & Grey (dark medium) \\
ISP3 & Good & Dark grey & Grey \\
ISP4 & Good & Grey & Grey \\
ISP5 & Moderate & Light pink & Greyish white \\
ISP6 & Good & White & Light grey \\
ISP7 & Good & Beige & Grey with white center \\
Glucose asparagine & Good & Grey white & Light grey \\
Starch casein & Good & White & Grey (dark medium) \\
Hickey and Tresner & Good & Dark grey pink & Dark grey (+pigment) \\
\hline
\end{tabular}

\section{Molecular identification}

16S rRNA gene sequence of SS strain was submitted in the GenBank database with accession number SUB6916285. Comparative analysis of this sequence with the corresponding sequences of other microorganisms obtained from the same database, found 24 most closely related species with a high degree of relatedness. The phylogenetic tree constructed by the Neighbor-Joining distance method is shown in Fig.1, Streptomyces roseolus NBRC $12816^{\top}$ is the closest species occupying the same phylogenetic line with high similitude degree (98.97), 30\% bootstrap support and a genetic distance of 0.74 . These two last observations assume that they are probably two different species despite the high degree of similarity. It is therefore necessary to use phenotypic characters and DNA-DNA hybridization to confirm.

Streptomyces roseolus NBRC $12816^{\top}=$ ATCC 23210 was first described by Preobrazhenskaya and Sveshnikova (1957) whose various phenotypic characters were detailed by Shirling and Gottlieb (1968a). According to the phylogenetic classification of Labeda et al. (2012), it is classified in group 43 with $100 \%$ bootstrap percentage with Streptomyces roseosporus CGMCC 4.1871 ${ }^{\top}$, both belonging to class 5 of the digital taxonomy phenotype of Williams et al. (1983). They have been considered synonymous in the Bergey's Manual of Systematic Bacteriology (Williams et al. 1989). 


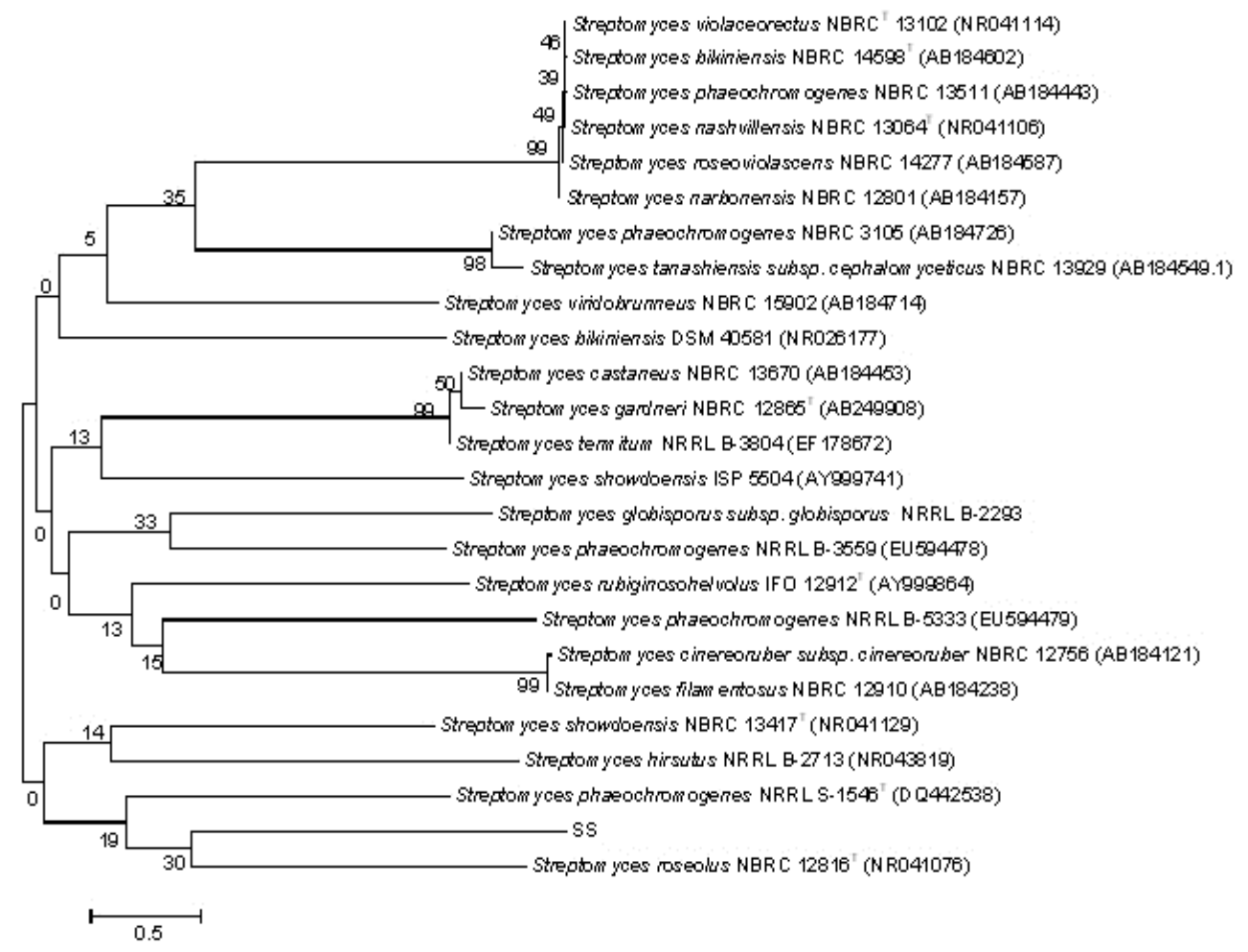

Fig. 1. Neighbour-Joining phylogenetic tree based on $16 \mathrm{~S}$ rRNA gene sequences showing SS strain and the nearest related taxa. (Numbers at nodes indicate percentages of 1000 bootstrap resampling. Bar equals 0.5 nucleotide substitutions per site).

\section{Physiological and biochemical characteristics}

SS strain had assimilated glucose, mannose, xylose, dextrins, galactose, arabinose, maltose and lactose (Table 3). It produced a melanoid pigment on ISP7, degraded starch, gelatin, casein, peptonised milk, reduced nitrates to nitrites and tolerated up to $3 \% \mathrm{NaCl}$. For the other characters, our strain did not use citrate, produced neither $\mathrm{H}_{2} \mathrm{~S}$ nor indole nor tryptophan deaminase but had urease and arginine decarboxylase. It did not develop at extreme temperatures $\left(4^{\circ} \mathrm{C}\right.$ and $\left.45^{\circ} \mathrm{C}\right)$ and showed optimal growth at $37^{\circ} \mathrm{C}$ and pH 6.0 to 6.5 (Table 3). 
Table 3. Physiological and biochemical characteristics of SS strain

\begin{tabular}{|c|c|}
\hline Tests & Results \\
\hline $\begin{array}{l}\text { Production of melanoid pigments } \\
\text { ISP } 6 \\
\text { ISP } 7\end{array}$ & $\begin{array}{l}-(1) \\
+\end{array}$ \\
\hline $\begin{array}{l}\text { Hydrolysis } \\
\text { Starch } \\
\text { Gelatin } \\
\text { Casein }\end{array}$ & $\begin{array}{l}+ \\
+ \\
+\end{array}$ \\
\hline $\begin{array}{l}\text { Skimmed milk hydrolysis } \\
\text { Peptonisation } \\
\text { Coagulation }\end{array}$ & $\begin{array}{l}+ \\
-\end{array}$ \\
\hline Nitrate reduction & + \\
\hline $\mathrm{NaCl}$ tolerance & $3 \%$ \\
\hline $\begin{array}{l}\text { Growth at different temperature values } \\
4^{\circ} \mathrm{C} \\
22^{\circ} \mathrm{C} \\
28^{\circ} \mathrm{C} \\
37^{\circ} \mathrm{C} \\
45^{\circ} \mathrm{C}\end{array}$ & $\begin{array}{c}\text { (Dry weight/40 ml) } \\
- \\
+(27.2 \mathrm{mg}) \\
+(42.7 \mathrm{mg}) \\
+(155 \mathrm{mg}) \\
-\end{array}$ \\
\hline $\begin{array}{l}\text { Growth at different } \mathrm{pH} \text { values } \\
5.5 \\
6.0 \\
6.5 \\
7.0 \\
7.5 \\
8.0\end{array}$ & $\begin{array}{l}+(2) \\
+++ \\
+++ \\
++ \\
++ \\
+\end{array}$ \\
\hline Citrate utilization & - \\
\hline $\mathrm{H}_{2} \mathrm{~S}$ production & - \\
\hline Indole production & - \\
\hline Tryptophane desaminase test & - \\
\hline $\begin{array}{l}\text { Decarboxylase test } \\
\text { Arginine } \\
\text { Lysine } \\
\text { Ornithine }\end{array}$ & $\begin{array}{l}+ \\
- \\
-\end{array}$ \\
\hline Urease test & + \\
\hline
\end{tabular}


Contd. Table 3

\begin{tabular}{|l|c|}
\hline \multicolumn{1}{|c|}{ Tests } & Results \\
\hline Degradation & \\
D - glucose & - \\
L - rhamnose & - \\
D - mannitol & $\neq$ \\
Mannose & $\neq$ \\
D - xylose & $\neq$ \\
Dextrine & $\neq$ \\
D - galactose & - \\
Sucrose & $\neq$ \\
L - arabinose & - \\
D - fructose & $\neq$ \\
Maltose & $\neq$ \\
Lactose & - \\
Raffinose & - \\
I - inositol & - \\
Cellulose & \\
\hline
\end{tabular}

(1) For tests: (+): Strain growth or positive test reaction; (-), No growth or negative test reaction, (2) Growth at different $\mathrm{pH}$ values: $(+++)$ : Good, (++): moderate, $(+)$ : poor.

Table 4 reports a comparison of SS strain phenotypic characteristics with the two most closely related species. Our strain had the same type of spore chain (rectiflexible) as the two species (Streptomyces roseolus, Streptomyces roseosporus), but aerial and substrate mycelia colours and pigments production were completely different. Also, strain SS differed from the two listed species in the assimilation of rhamnose. These ascertainments were corroborated by the low bootstrap value and the significant genetic distance between SS strain and Streptomyces roseolus. Finally, it can be concluded that this strain, isolated from a poorly exploited environment, probably corresponds to a new species. Nevertheless, the DNA-DNA hybridization method must be used with the closely related species to confirm our assumption. 
Table 4. Comparison of SS strain phenotypic characteristics with related species of the group 43

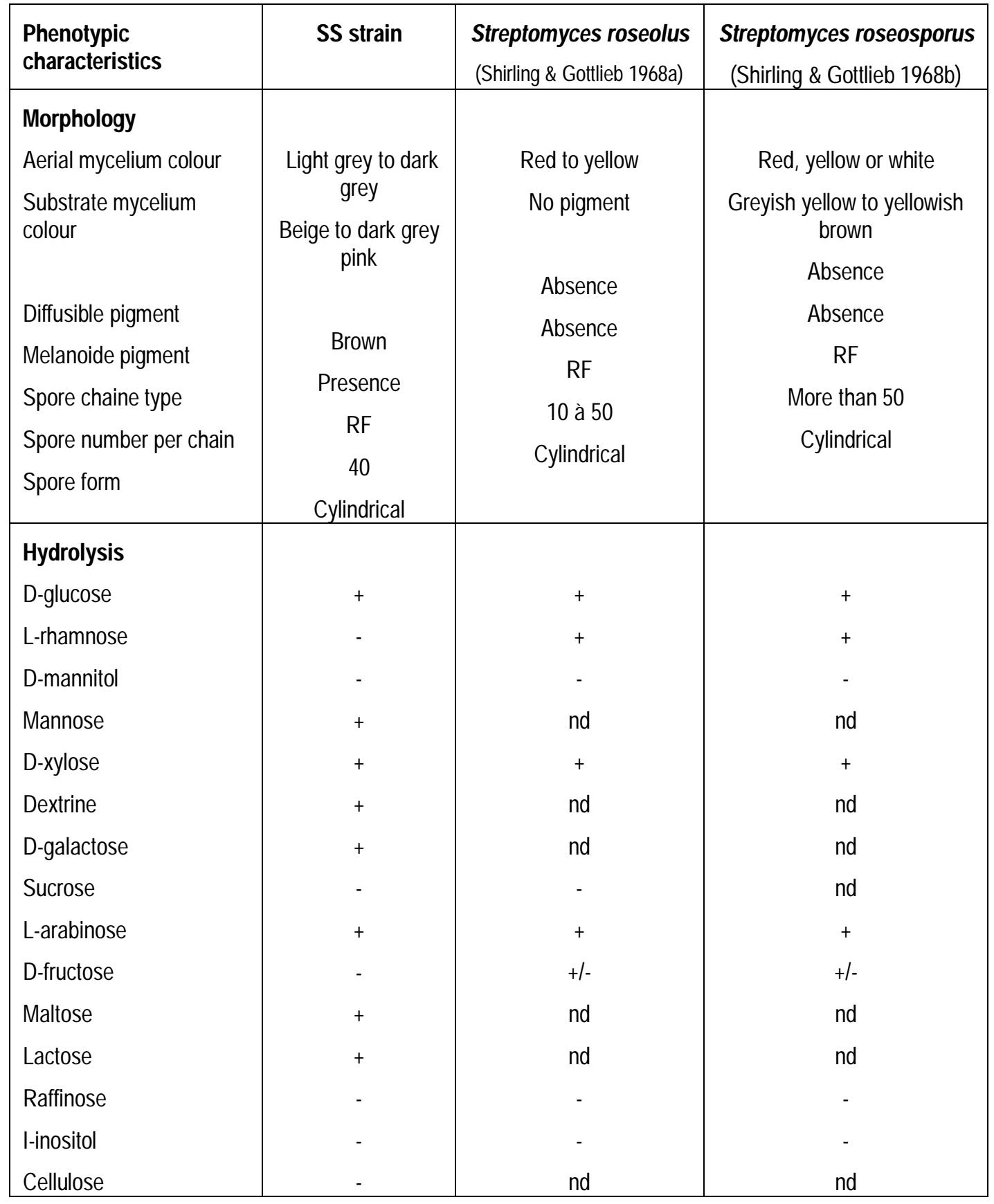

nd: not determined. 


\section{Optimization of wheat bran based medium for protease production}

\section{The effect of humidifying solution nature}

The addition of buffer solution to wheat bran, gave better protease production, followed by distilled water then salt solution (Fig. 2). This is probably due to the buffering capacity of the solution that was used as a partial $\mathrm{pH}$ control system. Indeed, during the culture, bacterial metabolic activity modifies the $\mathrm{pH}$ of the medium either by acidifying it (by the production of acids or by the absorption of ammonium ions), or by alkalinizing it (by the release of ammonia from the degradation of proteins, urea or other amines) (Manpreet et al. 2005).

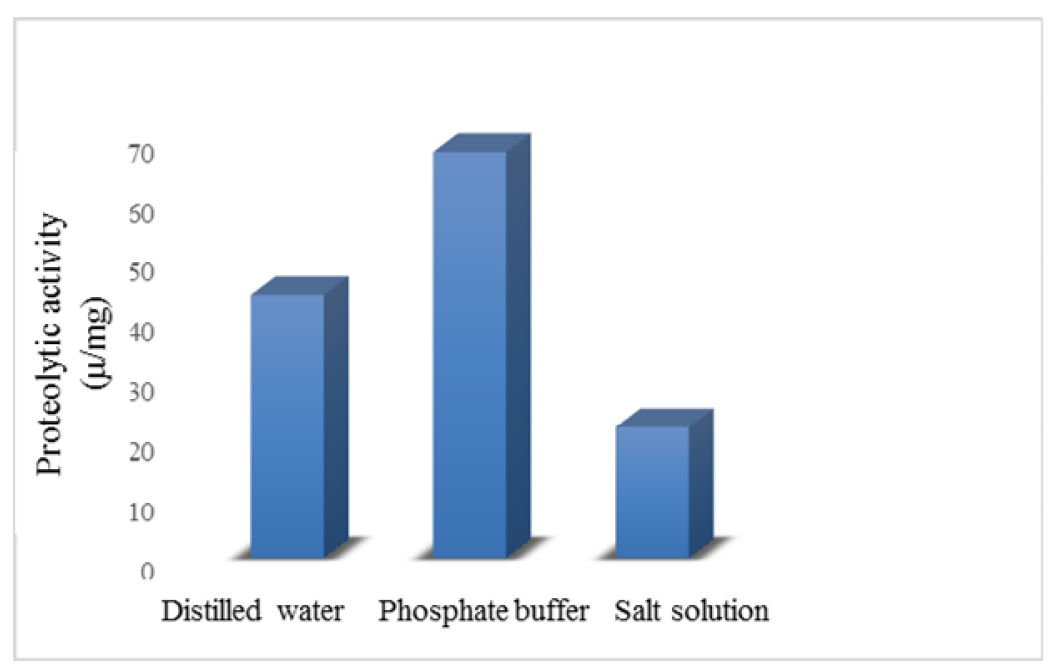

Fig. 2: Effect of humidifying solution nature on protease production in SSF using wheat bran as substrate.

\section{The effect of initial pH buffer solutions}

The results of this study revealed that buffer solution at $\mathrm{pH} 9$ added to the wheat bran, has ensured a better protease production (Fig. 3) followed by buffer solution at pH 10. However, a number of reports suggest $\mathrm{pH}$ $7.0-7.5$ to be optimal for protease production by bacteria and fungi. It has been reported that $E$. album BTMFS10 prefers both acidic $(\mathrm{pH} 4.0$ and 5.0$)$ and alkaline $(\mathrm{pH} 10.0)$ for protease production. A little acidic $\mathrm{pH}$ of 6.0 was found to be optimum for protease production by $P$. aeruginosa PseA. For $B$. circulans, pH 10 has been reported to be suitable for protease production. Protease production by $B$. subtilis remained approximately the same irrespective of the initial pH in the whole range tested (5.0 - 10.0) (Sharma et al. 2017).

In fact, microorganism's metabolic activities are very sensitive to $\mathrm{pH}$ variations that affect strongly the different enzymatic processes as well as nutrients transport through the cell membrane (Sandhya et al. 2005, Lazim et al. 2009, Paranthaman et al. 2009). These metabolic activities lead in turn, to a change in the hydrogen ions balance and therefore the pH of the culture medium (Elibol and Moreira 2005). 


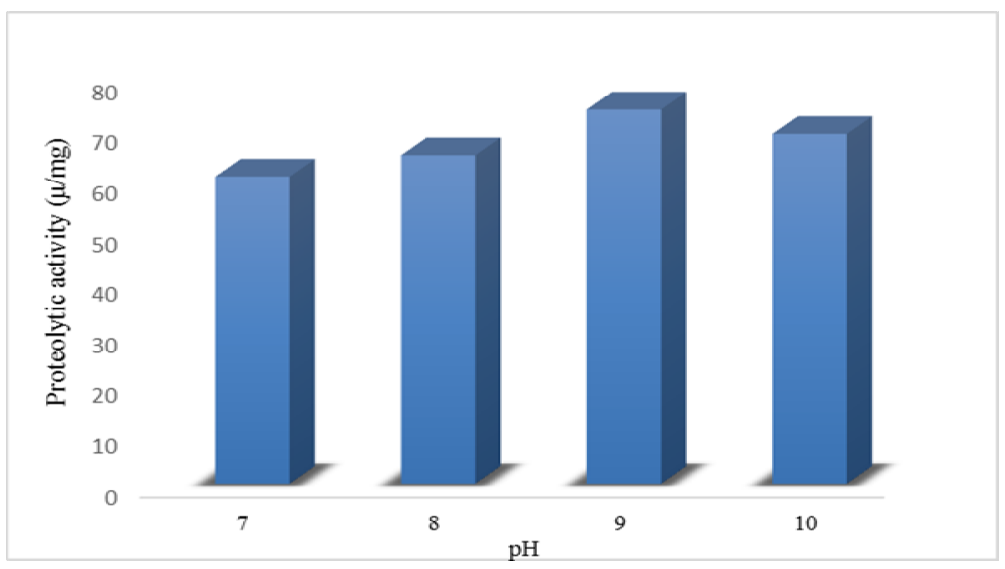

Fig. 3: Effect of initial pH buffer solutions on protease production in SSF using wheat bran as substrate.

\section{The effect of initial moisture content}

In SSF, the moisture content is an important factor that influences the growth and product yield of microbes (Ramesh and Lonsane 1990). Moisture was reported to cause swelling of the substrates, thereby facilitating better utilization of the substrate by microorganisms (Kim et al. 1985, Nagendra and Chandrasekharan 1996). The data presented in Fig. 4, indicated clearly a maximum production of the enzymes at $50 \%$ moisture. Agrawal et al. (2005) reported $50 \%$ of initial moisture content to be best for protease production by Penicillium sp. Similar observation has been reported by other workers for A. oryzae NRRL 2217, A. oryzae CFR305 and P. aeruginosa PseA (Sharma et al. 2017). The water content, or rather the amount of water available, is really important since low humidity would limit substrate hydrolysis, solubilisation and nutrient diffusion, while high humidity would reduce porosity (interparticular space), gas volume and gas exchange and also promote bacterial contamination.

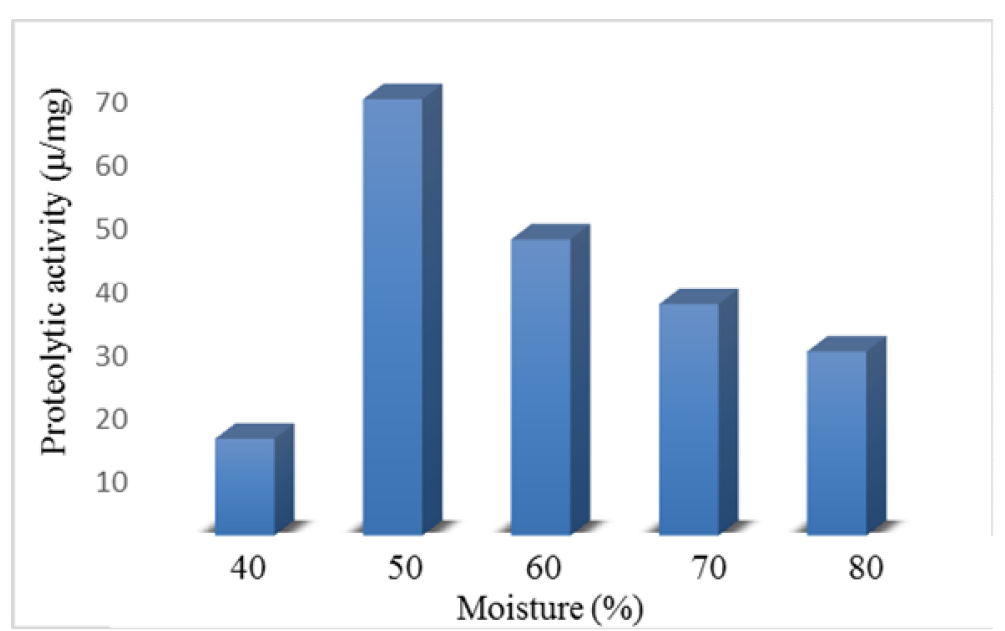

Fig. 4: Effect of moisture $\%$ on the production of protease in SSF using wheat bran as substrate. 


\section{The effect of supplementation carbon and nitrogen sources and salts on protease production}

The statistical analysis of the results, carried out by the Minitab 17 software and presented in Table 5, showed a significant effect of the factor X2 (Fructose) with a Student value of 2.99. It is therefore the only factor having a positive effect on the production of the protease by the strain SS, while the other source of carbon (glucose) and nitrogen sources (casein and gelatin) and $\mathrm{NaCl}$ showed no significant effects. Much research has shown that the addition of fructose to the culture medium increases greatly the protease production by certain molds such as Alternaria (Vandakini and Shastri 1983) and Aspergillus sp. (Radha et al. 2012). Our results also corroborate those of Eman et al. (2012), who demonstrated that carbon sources have a significant effect on protease production by Streptomyces griseus. On the other hand, casein which can serve as a substrate for proteolytic enzymes did not show a significant effect on protease production by the strain. This protein is a source of nitrogen which has a low solubility, which gives a low yield of proteolytic activity in solid medium. Several studies of microbial protease production in solid medium have confirmed our results (Jignasha and Satya 2007, Eman et al. 2012, Abdelwahed et al. 2014). In addition, Lazim et al. (2009) showed that the addition of casein in wheat bran solid culture medium did not increase protease production in Streptomyces sp.

Table 5. Statistical parameters for Plackett and Burman design (Minitab17 software)

\begin{tabular}{ccccc}
\hline Term & Effect & Coefficient & T value & P value \\
\hline$X_{1}$ & 0.73 & 0.36 & 0.06 & 0.956 \\
$X_{2}{ }^{*}$ & 35.18 & 17.59 & 2.99 & 0.096 \\
$X_{4}$ & 0.15 & 0.08 & 0.01 & 0.991 \\
$X_{5}$ & 6.19 & 3.10 & 0.53 & 0.651 \\
$X_{7}$ & 2.16 & 1.08 & 0.18 & 0.871 \\
\hline
\end{tabular}

T: Student test, $p$ : probability, *: Statistically significant, $R^{2}=65 \%$. Regression equation: Activity $=57.29$ $+0.36 X_{1}+17.59 X_{2}+0.08 X_{4}+3.10 X_{5}+1.08 X_{7}$

\section{The effect of $\mathrm{pH}$ on protease activity}

According to Fig. 5 , an increase in the proteolytic activity from pH 3.0 to $\mathrm{pH} 7.0$ was observed, beyond this value, the activity decreases considerably, which supposes the presence of a neutral protease with an optimum pH of 7.0, these results corroborate with those of Jignasha and Satya (2007) who demonstrated that actinobacteria and mainly those belonging to the genus Streptomyces are large producers of neutral proteases. 


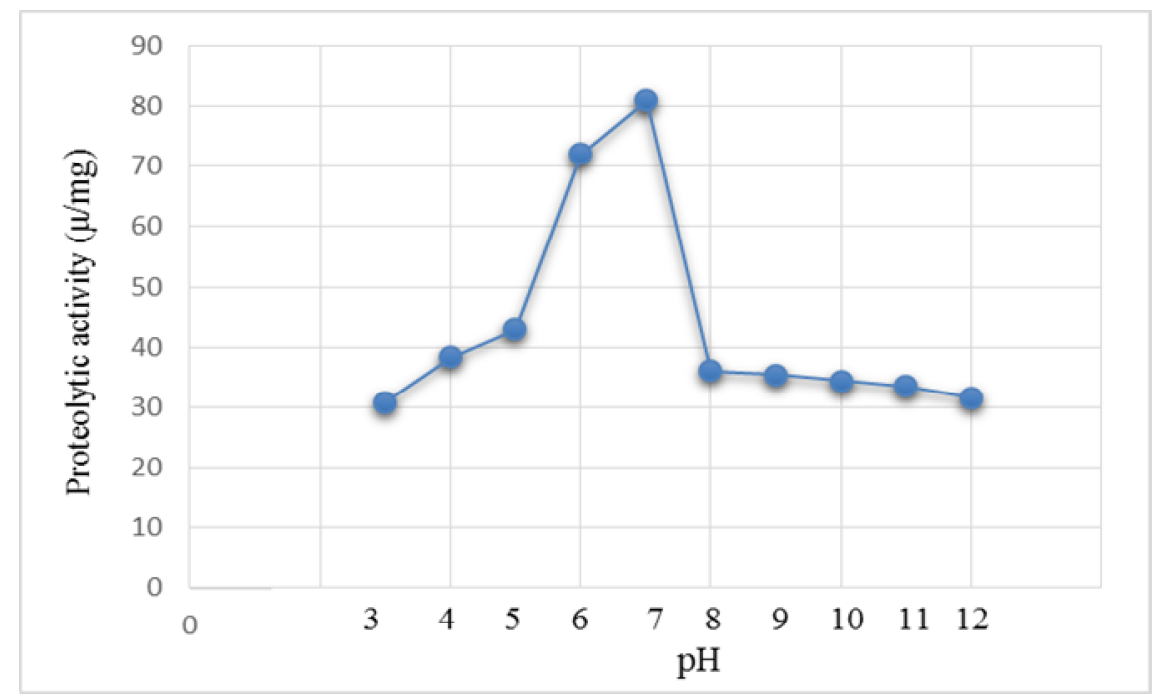

Fig. 5: Effect of pH on protease activity.

\section{The effect of temperature and thermal stability of the enzyme}

The enzyme activity increases in the temperature range between 20 to $60^{\circ} \mathrm{C}$ to reach the maximum activity at $60^{\circ} \mathrm{C}$ (Fig. 6). Beyond this temperature, the proteolytic activity decreases considerably. At $90^{\circ} \mathrm{C}$, the enzyme loses most of its activity. It is important to note that the enzyme has activity over a wide temperature range (significant activity between 40 and $80^{\circ} \mathrm{C}$ ), which is similar to the work reported by Sanchez-Porro et al. (2003), who showed that the Pseudoaltermonas sp. protease is active in a temperature range of 25 to $75^{\circ} \mathrm{C}$.

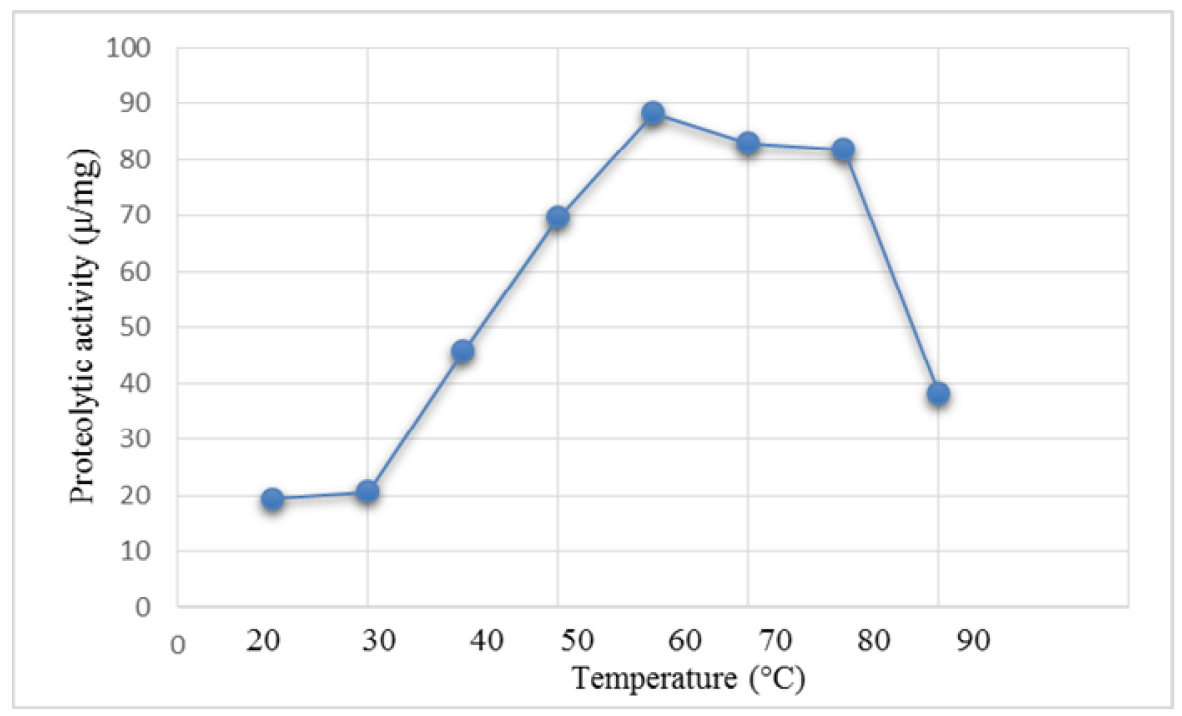

Fig. 6: Effect of temperature on protease activity. 
On the other hand, our results showed a significant thermal stability (Fig. 7). Indeed, at 60,70 and $80^{\circ} \mathrm{C}$ this enzyme has kept more than $90 \%$ of its activity after $120 \mathrm{~min}$. At $90^{\circ} \mathrm{C}$ the proteolytic activity has decreased considerably but it was persisting even after 90 min of heating.

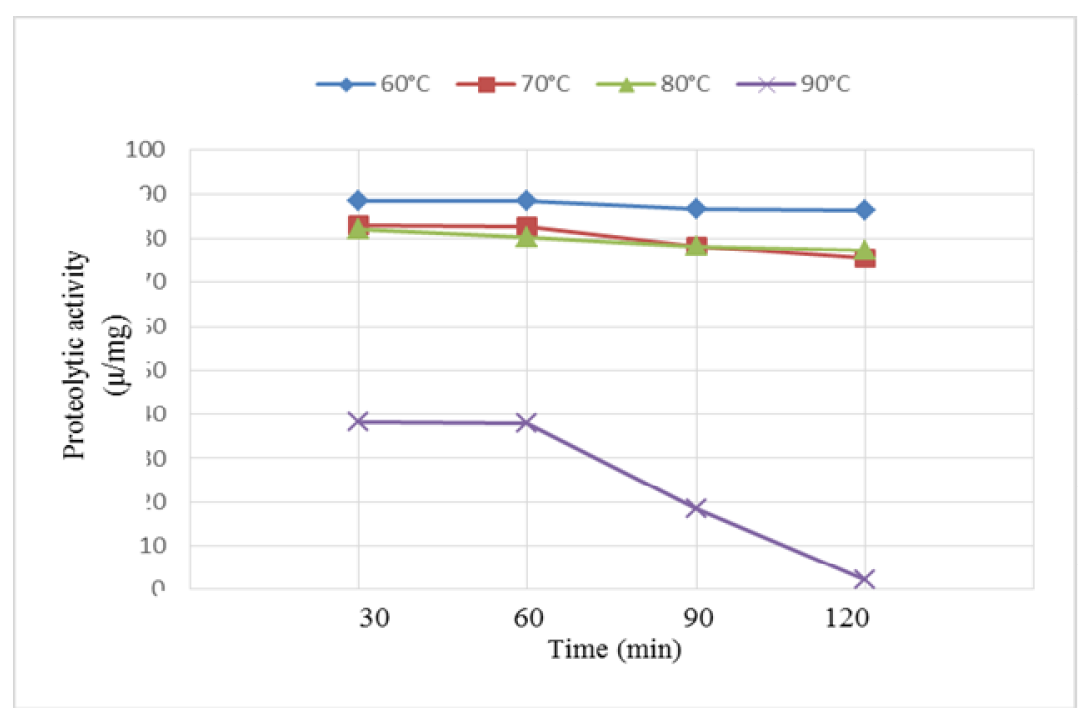

Fig. 7: Protease thermal stability study.

\section{Conclusion}

In conclusion, the newly Streptomyces sp. SS strain isolated from Saltpans which are rare regions in the world, was able to produce protease enzyme by SSF on wheat bran. It belongs probably to a new species within the genus Streptomyces according to genotypic and phenotypic data. The best protease producing medium based on wheat bran was moistened with $50 \%$ of pH 9.0 buffer solution and supplemented with $1 \%$ fructose. Protease had an optimum at pH 7.0, which is a typical characteristic of neutral proteases. The optimum temperature was $60^{\circ} \mathrm{C}$ and proved stable up to $80^{\circ} \mathrm{C}$. All these results show the high biotechnological potential of this Streptomyces strain for the production of the thermostable neutral protease since they could greatly reduce the overall cost of enzyme production.

\section{Acknowledgements}

The authors would like to express their deepest appreciation and gratitude to Dr. Aitkaki Amel (Mentouri Brother University, Constantine 1) and Dr. Beatrice Lauga, University of Pau and Pays de l'Adour, France for their crucial contribution to this study.

Conflict of interests: The authors declare that there is no conflict of interests.

\section{References}

Abdelwahed NAM, Danial EN, El-naggar NEA and Mohamed AA (2014). Optimization of alkaline protease production by Streptomyces ambofaciens in free and immobilized. Am J Biochem Biotechnol., 10: 1-13.

Agrawal D, Patidar P, Banerjee T and Patil S (2005). Alkaline protease production by a soil isolate ofBeauveria felinaunder SSF condition: parameter optimization and applicationto soy protein hydrolysis. Process Biochemistry, 40: 1131-1136. 
Bhunia B, Bikram B, Pinaki B and Apurba D (2012). Kinetic studies of alkaline protease from Bacillus licheniformis NCIM2042. J Microbiol Biotechnol., 22: 1758-1766.

Chaphalkar SR and Dey S (1996). Computer assisted identification of Streptomyces species with high extracellular protease activity. Actinomycete, 7: 47-54.

Crawford DL, Lynch JM and Ousley MA (1993). Isolation and characterisation of actinomycetes antagonists of a fungal root pathogen. Appl Environ Microbiol., 59: 3899-3905.

Elibol M and Moreira A (2005). Optimizing some factors affecting alkaline protease production by a marine bacterium Teredinobacter turnirae under solid substate fermentation. Process Biochem., 40: 1951-1956.

Eman W, El-Gammal DE, El-Hadedy M, Saad M and Moharib SA (2012). Optimization of the Environmental Conditions for alkaline protease production using Streptomyces griseus in Submerged Fermentation Process. Aust J Basic Appl Sci, 6: 643-653.

Holt JG, Krieg NR, Sneath PHA, Staley J and Williams ST (1994). Bergey's Manual $®$ of Determinative Bacteriology, Williams \& Wilkins, USA, pp. 611-703.

Jayasree D, Sandhya Kumara TD, Kavi Kishor PB, Vijaya Lakshmi M and Lakshmi Narasu M (2009). Optimization of production protocol of alkaline protease by Streptomyces pulvereceus. Inter Sci Technol., 1: 79- 82.

Jignasha TT and Satya PS (2007). Secretion of an alkaline protease from a salt-tolerant and alkaliphilic, Streptomyces clavuligerus strain mit-1. Braz J Microbiol., 38: 766-772.

Kim JH, Hosobuchi M, Kishimoto M, Seki T and Ryu DDY (1985). Cellulase production by a solid state culture system. Biotechnol Bioeng., 27: 1445-1450.

Labeda DP, Goodfellow M, Brown R, Ward AC, Lanoot B, Vanncanneyt M, Swings J, Kim SB, Liu Z, Chun J, Tamuta T, Oguchi A, Kikuchi T, Kikuchi H, Nishii T, Tsuji K, Yamaguchi Y, Tase A, Takahashi M, Sakane TI and Hatano K (2012). Phylogenetic study of the species within the family Streptomycetaceae. Antonie van Leeuwenhoek, 101: 73-104.

Lazim H, Mankai H, Slama N, Barkallah I and Limam F (2009). Production and optimization of thermophilic alkaline protease in solid-state fermentation by Streptomyces sp. CN902. J Ind Microbiol Biotechnol., 36: 531-537.

Lonsane BK and Ramesh MV (1990). Production of bacterial thermostable a-amylase by solid-state fermentation: a potential tool for achieving economy in enzyme production and starch hydrolysis. Adv. Appl. Microbiol., 35: 1-56.

Manpreet S, Sawraj S, Sachin D, Pankaj S and Banerjee UC (2005). Influence of Process Parameters on the Production of Metabolites in Solid-State Fermentation. Malays J Microbiol., 1: 1-9.

Nagendra PG and Chandrasekharan M (1996). L-glutaminase production by marine Vibrio costicola under solid state fermentation using different substrates. J Mar Biotechnol., 4: 176-179.

Padmapriya M and Christudhas WB (2012). Purification and characterization of neutral protease enzyme from Bacillus Subtilis. J Microbiol Biotechnol Res., 2: 612-618.

Pandey A (1992). Recent process developments in solid-state fermentation. Process Biochem, 27: 109-117.

Paranthaman R, Alagusundaram K and Indhumathi J (2009). Production of protease from rice mill wastes by Aspergillus niger in solid state fermentation. World J Agric Sci., 5: 308-312.

Plackett RL and Burman JP (1946). The design of optimum multifactorial experiments. Biometrika, 33: 305-325.

Preobrazhenskaya TP and Sveshnikova MA (1957). Streptomyces. In: Gauze GF, Preobrazhenskaya TP, Kudrina ES, Blinov NO, Ryabova ID and Sveshnikova MA (Eds.). Problems of classification of actinomycetes- antagonists. Government, Publishing House of Medical Literature Moscow, pp. 1-39. 
Radha A, Sridevi R, Himakiranbabu VJ, Nithya NBL and Narasim HG (2012). Medium optimisation for acid protease production from Aspergillus sp under solid state fermentation and mathematical modelling of protease activity. J Microbiol Biotechnol Res., 2: 6-16.

Ramesh MV and Lonsane BK (1990). Critical importance of moisture content of the medium in a-amylase by Bacillus licheniformis M27 in a solid-state fermentation system. Appl Microbiol Biotechnol., 33: 501-505.

Saitou N and Nei M (1987). The neighbor-joining method: a new method for reconstructing phylogenetic trees. Mol. Biol. Evol., 4: 406-425.

Sanchez-Porro C, Mellado E and Ventosa A (2003) Screening and characterization of the protease CP1produced by themoderately halophilic bacterium Pseudoalteromonas sp. Strain CP76. Extremophiles, 7:221-228.

Sandhya C, Nampoothiri KM and Pandey A (2005). Microbial proteases. Methods in Biotechnology, 17:165-179.

Sanger F, Nicklen S and Coulson AR (1977). DNA sequencing with chain-terminating inhibitors. Proceeding of the National Academy of Sciences of USA, 74: 5463-5467.

Sankaralingam S, Ramasubburayan R and Palavesam A (2012). Optimization of culture conditions for the production of an extracellular alkaline protease from Vibrio mimicus. Proceeding of international conference on environment, energy and biotechnology Kual Lumpur, Malaysia.

Sharma KM, Kumar R, Panwar S and Kumar A (2017) Microbial alkaline proteases: Optimization of production parameters and their properties. Journal of Genetic Engineering and Biotechnology,15: 115-126.

Shirling EB and Gottlieb D (1966). Methods for characterization of Streptomyces species. Inter J Syst Bacteriol., 16: $313-340$

Shirling EB and Gottlieb D (1968a). Cooperative description of type cultures of Streptomyces. II. Species descriptions from first study. Inter J Syst Bacteriol., 18: 69-189.

Shirling EB and Gottlieb D (1968b). Cooperative description of type cultures of Streptomyces. III. Additional species descriptions from first and second studies. Inter J Syst Bacteriol, 18: 279-392.

Singleton P (1999). Bacteria in biology, bacteriology and medicine, Wiley ed. Chichester, UK, pp.1- 236.

Tamura K, Peterson D, Peterson N, Stecher G, Nei M and Kumar S (2011). MEGA5: molecular evolutionary genetics analysis using likelihood, distance, and parsimony methods. Mol Biol Evol., 28: 2731-2739.

Tsuchida O, Yamagata Y, Ishizuka J, Arai J, Yamada J, Takeumi M and Ichishima E (1986). An alkaline proteinase of an alkalophilic Bacillus sp. Curr Microbiol., 14: 7-12.

Vandakini P and Shastri NV (1983). Effect of fructose on extracellular Alternaria alternata production of proteases. Indian Institute of Science, 64: 111-120.

Williams ST and Cross T (1971). Actinomycetes. In: Methods in microbiology. Academic Press, London, pp. 295-334.

Williams ST, Goodfellow M and Alderson G (1989). Genus Streptomyces. In: Williams ST, Sharpe ME and Holt JH (Eds.), Bergey's Manual of Systematic Bacteriology, USA, Vol. 4, pp. 2452-2492.

Williams ST, Goodfellow M, Alderson G, Wellington EMH, Sneath PHA and Sackin MJ (1983). Numerical classification of Streptomyces and related genera. J Gen Microbiol., 129: 1743-1813.

Zaitlin B, Watson S, Dixon J and Steel D (2003). Actinomyetes in Elbow River Basin Alberta Canada. Water Qual Res J Canada, 38: 115-125.

(Manuscript received on 10 May 2020; revised on 10 July 2020) 